\title{
COMPARISONS OF FARMERS' INCOME AND CAPITAL CREATION BASE ON DIFFERENT SOURCES OF RICE FARMING FINANCING IN SOUTH SUMATRA, INDONESIA
}

\author{
Hamzah Maryanah*, Bidarti Agustina, Anggraini Erise, Antoni Mirza \\ University of Sriwijaya, Indonesia \\ *E-mail: maryanahhamzah@fp.unsri.ac.id
}

\begin{abstract}
The objective of the research was to compare rice farmers' income and capital creation base on a different source of rice farming financing. The study population comprised 180 farmers, 105 of which represented the own funding farmers and the rest were loan funding farmers. These were interviewed to record the rice farming behavior with a different financial source in the sixth bigger rice production in Indonesia, namely South Sumatera Province. Rice farming analysis and continued t-test was used to analyze for different production and income. Research results showed that rice productivity of own funding rice's farmers was $29 \%$ greater than farmers on loan funding farmers. On the other hand, producing cost of own funding farmers $26 \%$ was lower than loan funding farmers. This condition causes the income of own funding rice's farmers per hectare $56 \%$ was greater than the income of loan funding farmers. Moreover, with the family spending were not too different, capital creation of own funding farmers was greater than loan funding farmers. Almost half of the farmers have a medium level of capital creation capability, the remaining one third was more classified as high capital creation and one-eighth was classified as low. To reduce rice farming cost of loan funding farmers are savings of labor costs by supervising their labor and finding sources of loans with the lowest loan interest rates.
\end{abstract}

\section{KEY WORDS}

Rice farming financing, capital creation, own funding, loan funding.

Indonesia is the third largest rice producing country in the world with paddy production in 2017 amounting to 70 million tons, equivalent to 39 million tons of rice. China is the first largest rice producer with a production of 115 million tons. Meanwhile, Indonesia's rice consumption per year was 32 million tons, so there is a surplus of seven million tons of rice. This rice consumption continues to increase as a result of increasing population. The population increases 3.2 million or grows 1.27 percent per year. Indonesian rice consumption is still high at $114.6 \mathrm{~kg}$ per capita per year so that if production is only slightly disrupted, a rice deficit will occur and must import (Ministry of Agiculture Republic of Indonesia, 2017).

Importing rice turned out to be very profitable because rice price in neighboring riceproducing countries was lower than in Indonesia. Cambodian rice prices were US $\$ 0.42 / \mathrm{kg}$, Thailand US \$ $0.33 / \mathrm{kg}$, Vietnam US \$ $0.31 / \mathrm{kg}$ and in Myanmar even US \$ $0.28 / \mathrm{kg}$, while the price of Indonesian rice was US \$1/kg.

The high price of rice in Indonesia was due to higher production costs. Indonesian rice production costs were Rp 4,079 per kilogram, while in China it was only Rp 3,661 per kg, Philippines Rp 3,224 per kg, Thailand Rp 2,291 per kg, even in Vietnam only Rp 1,679 per $\mathrm{kg}$. The high cost of Indonesian rice production was because of the high cost of land rent and the cost of freelance labor. Rent of agricultural land in Indonesia contributes to production costs of Rp 1,719 per kg. While in China only Rp. 988 per kg, Philippines Rp. 549 per kg, India Rp. 510 per kg, Thailand Rp. 481 per kg, and Vietnam Rp. 387 per kg. Similarly, the cost of freelance workers in Indonesia was also the most expensive, which reaches Rp 1,115 per kg, while in the Philippines only Rp 978 per kg, China Rp 127 per kg, India Rp 655 per kg, Thailand Rp 172 per kg, and Vietnam Rp 120 per kg (detikFinance, 2017).

The high cost of production has implications for the high in funding for rice farming, which sometimes farmers are not covered by their own fundings. If they get it from 
borrowing, the production costs will increase. These borrowing costs are lower if they loan to the government. But if they borrow from non-governmental and non-formal institutions, then the interest is higher. Loan interest varies, but generally reaches 50 percent per planting season.

Indonesia's rice production is concentrated in Java, which is $56 \%$ with East Java as the first largest province with the production of 13.13 million tons or $16.1 \%$ of total national production. South Sumatra is the sixth largest rice producing province in Indonesia with production in 2017 of 4.8 million tons (Ministry of Agiculture Republic of Indonesia, 2017). There are four land typologies in South Sumatra where they are produced, namely tidal swamp, irrigation, swamp, and rainfed land. The total rice harvest area in South Sumatra in 2017 is 1.014 million hectares. Of the four types of land, three of them are classified as marginal land: tidal swamp, swamp, and rainfed land. The biggest production was contributed by tidal swamp with a contribution of $30 \%$, while the irrigated land was $21 \%$, rainfed land $14 \%$ and swamp $12.5 \%$ (The Central Bureau of Statistics, South Sumatera, 2017).

The role of rice farming in producing rice has not yet received enough attention from the government, especially in the problem of farming financing. There are still very few farmers who use loan sources from formal institutions such as banking (Mulyaqin and Astuti, 2013). Complicated procedures and strict requirements from banks caused farmers to borrow for rice farming costs to non-formal institutions such as middlemen, paddy's mills and loan sharks. The results of the study on South Sumatra rainfed land rice farming (Antoni et al., 2015) showed that 33 percent of farmers' rice farming costs came from loans, both from formal and non-formal institutions. The study also found that there were differences in production between farmers using their own capital and loan capital, although the income side was not different. The same studies on the tidal swamp, swamps, and irrigation have not been done. Therefore a study of the effect of the sources of farming costs on income and the creation of farmers' capital in all land ecosystems in South Sumatra needs to be done.

\section{METHODS OF RESEARCH}

The survey was conducted in three villages of the three largest rice ecosystems in South Sumatra while representing three different districts. Banyuasin Regency as the largest rice producer represents tidal swamp rice farming, Ogan Komering Ulu Timur Regency, representing the technical irrigation ecosystem and Ogan Komering Ilir District which represents the widest swampland area. Farmer samples were selected using disproportionate stratified random sampling with the number of samples in each village 60 so that the total sample was 180. The samples divided into two groups based on funding sources, own funding and loan funding.

The data was presented in tabulation, processed mathematically and explained descriptively. Differences in production and income based on different sources of financing were used the t-test (Jhonson, 1982), while capital creation was family income minus family expenditure. Then to measure the level of capital creation ability was divided into three groups: high, medium and small.

\section{RESULTS AND DISCUSSION}

Differences in Production and Rice Farming Income. There was a difference in the frequency of rice cultivation carried out by farmers among three paddy land ecosystems. In technical irrigated land, farmers usually plant twice a year, while in swamp land there was only once a year and in tidal swamp land, there were some farmers plant twice a year. Data on the comparison of rice production based on farming and ecosystem funding sources are presented in Table 1. The forms of rice production shown in Table 1 are harvested dry grain. Based on the data presented in Table 1, the production per hectare of own funding farmers was 29 percent greater than the loan funding farmers with a difference of 1,406 kilograms per hectare per year. This large difference is contributed by tidal swamp land, which is more 
than twice and 20 percent in swamp land, while that of irrigated land is relatively small at only four percent. Statistically, there is a significant difference between the income of own funding and loan funding farmers at a significant level of $1 \%$.

Table 1 - Production dan paddy farming income in South Sumatera, 2017

\begin{tabular}{ccccc}
\hline \multirow{2}{*}{ Sources of Funding } & \multicolumn{4}{c}{ Typology of Land } \\
\cline { 2 - 5 } & Irrigation & Swamp & Tidal Swamp & Average \\
\hline Own Funding & & & & \\
- Production (kg/ha) & 6,009 & 4,528 & 8,360 & 6,299 \\
- Price (IDR/kg) & 4,216 & 5,090 & 4,317 & 4,541 \\
- Revenue (IDR/ha) & $25,329,210$ & $23,049,898$ & $36,085,302$ & $28,154,803$ \\
Loan Funding & & & & \\
- Produciton (kg/ha) & 5,756 & 3,777 & 5,145 & 4,892 \\
- Price (IDR/kg) & 4,227 & 5,113 & 4,193 & 4,511 \\
- Revenue (IDR/ha) & $24,326,815$ & $19,312,160$ & $21,573,772$ & $21,737,582$ \\
Differences & & & & \\
- Production (kg/ha) & 253 & 752 & 3,215 & 1,406 \\
- Percentage (\%) & 4 & 20 & 62 & 29 \\
- Price (IDR/kg) & -11 & -23 & 123 & 30 \\
- Percentage (\%) & $-0,26$ & $-0,46$ & 2,94 & 0,66 \\
- Revenue (IDR/ha) & $1,002,396$ & $3,737,738$ & $14,511,530$ & $6,417,221$ \\
- Percentage (\%) & 4 & 19 & 67 & 30 \\
\hline
\end{tabular}

Source: The farmers survey by the author, 2018.

This large production difference occurs on marginal land. Swamp and tidal swamp land are classified as marginal land because they are not as fertile as technical irrigation land. Although tidal swamp land also has irrigation, but a tidal swamp and tidal factors and salt water, this land is not as fertile as technical irrigation land.

The greater difference in production per hectare on marginal land between own funding farmers and loan funding farmers indicate that the production input needs must be met in this type of land. Paddy will produce high production if use enough production input. In contrast, loan funding farmers did not use production inputs as much as own funding farmers. This situation can impact on low production in loan funding farmers.

Fixed costs are generally relatively small because they are calculated from the depreciation costs of equipment used in rice farming for one year. The method of calculating the depreciation value was the straight-line method. This method assumed the same depreciation value every year during economic life. The equipment used in rice farming as presented in Table 2 is hoes, sickles, big knife, hand sprayer and "tunjams".

Table 2 - The fixed cost of paddy farming in South Sumatera, 2017

Source: The farmers survey by the author, 2018.

Based on Table 2, the fixed costs of paddy farming are relatively small at less than Rp. 500,000 per year per hectare. The fixed costs of own funding farmers were greater than loan funding farmers, although the difference was small, which is only Rp 12,010 per year per hectare. The biggest fixed costs occurred in tidal swamp land, while the smallest occurred in 
the swamp land. Input price of fixed costs components on tidal swamp land was expensive. This location is far from where the input was traded, Palembang city. On the contrary, low fixed costs on swamp land because the input production is easy to get in the district market. This means that the cost of rice producing depends also on how far the location of the distribution center of the production input to rice farming location.

Variable costs in this study were all costs incurred which depend on the amount of production that will be produced. Generally, variable costs are materials, but in this study, services are also included in variable costs such as labor, equipment rental, loan interest, transportation and, land rent. Therefore, there are seven components of variable costs in rice farming as presented in Table 3.

Table 3 - The variable cost of paddy farming in South Sumatera, 2017

Source: The farmers survey by the author, 2018.

Based on the data presented in Table 3, the cost of producing rice farming for loan funding farmers was greater than own funding farmers. This difference was due to in large contribution of loan interest cost and land rent, especially in the swamp land area. The biggest contribution of variable costs comes from labor costs, both for loan funding farmers and own funding farmers. Rice farming is not enough if they use from family labor, especially in planting and harvesting activities. In those activities must be done immediately and requires a lot of labor.

Based on Table 4, the cost of producing rice farming for loan funding farmers was around more IDR 1 million per hectare than own funding farmers. Almost all of the production costs come from variable costs, $96 \%-97 \%$. The biggest production cost of rice farming on loan funding farmers at swamp land, while the lowest is for irrigated on own funding farmers. This result shows that the production costs in swamp land are less economical when viewed from the side of production costs compared to in the irrigation and tidal swamp land types.

Table 4 - The production cost of rice farming in South Sumatera, 2017 
The income is the difference between the revenue and production costs of rice farming. This income calculates rice production consumed, so it is not real income. The income of rice farming in three different types of land is presented in Table 5.

Based on the data presented in Table 5, the rice income of own funding farmers per hectare was $56 \%$ greater than the income of loan funding farmers. This condition was due to revenue of own funding farmers being greater than $30 \%$ and production costs $26 \%$ lower than loan funding farmers. The high revenue of own funding farmers was because of higher production of $29 \%$, while prices are relatively no different. The biggest income difference occurs in tidal swamp land which was around twice, whereas in swamp land one and a half times and in irrigated land was $18 \%$. In statistically there were differences in income with a significant level of $5 \%$.

Table 5 - Income of paddy farming in South Sumatera, 2017

\begin{tabular}{|c|c|c|c|c|}
\hline \multirow{2}{*}{ Income by Funding Source (IDR/ha) } & \multicolumn{4}{|c|}{ Typology of land } \\
\hline & Irrigation & Swamp & Tidal Swamp & Average \\
\hline \multicolumn{5}{|l|}{ Own Funding } \\
\hline - Revenue & $25,329,210$ & $23,049,898$ & $36,085,302$ & $28,154,803$ \\
\hline - Production Cost & $3,160,662$ & $5,891,524$ & $6,336,837$ & $5,129,674$ \\
\hline - Income & $22,168,548$ & $17,158,374$ & $29,748,465$ & $23,025,129$ \\
\hline \multicolumn{5}{|l|}{ Loan Funding } \\
\hline - Revenue & $24,326,815$ & $19,312,160$ & $21,573,772$ & $21,737,582$ \\
\hline - Production Cost & $5,616,132$ & $9,134,409$ & $6,050,305$ & $6,933,615$ \\
\hline - Income & $18,710,683$ & $10,177,752$ & $15,523,467$ & $14,803,967$ \\
\hline \multicolumn{5}{|l|}{ Differences } \\
\hline - Revenue & $1,002,396$ & $3,737,738$ & $14,511,530$ & $6,417,221$ \\
\hline - Percentage (\%) & 4 & 19 & 67 & 30 \\
\hline - Production Cost & $-2,455,470$ & $-3,242,884$ & 286,532 & $-1,803,941$ \\
\hline - Percentage (\%) & -44 & -36 & 5 & -26 \\
\hline - Income & $3,457,865$ & $6,980,622$ & $14,224,997$ & $8,221,162$ \\
\hline - Percentage (\%) & 18 & 69 & 92 & 56 \\
\hline
\end{tabular}

Source: The farmers survey by the author, 2018.

Table 6 - Household income of rice farming in South Sumatera, 2017

\begin{tabular}{ccccc}
\hline Typology of Land & Rice Farming & Non-Rice Farming & Non- Farming & Total \\
\cline { 2 - 5 } & & & & \\
\hline Irrigation & $11,576,909$ & 208,889 & $2,589,244$ & $14,375,042$ \\
Own Funding & $11,226,410$ & 133,333 & 800,000 & $12,159,743$ \\
Loan Funding & & & & \\
Swamp & $19,589,143$ & $3,446,667$ & $20,563,333$ & $43,599,143$ \\
Own Funding & $11,857,081$ & $6,116,667$ & $4,910,000$ & $22,883,747$ \\
Loan Funding & & & & $42,143,658$ \\
Tidal Swamp & $42,143,658$ & 0 & 0 & $34,695,864$ \\
Own Funding & $29,235,864$ & 100,000 & $5,360,000$ & $33,372,615$ \\
Loan Funding & & & & $23,246,451$ \\
Average & $24,436,570$ & $1,218,519$ & $7,717,526$ & $10,126,163$ \\
Own Funding & $17,439,785$ & $2,116,667$ & $3,690,000$ & 44 \\
Loan Funding & $6,996,785$ & $-898,148$ & $4,027,526$ & 109 \\
Difference & 40 & -42 & & 4 \\
Percentage $(\%)$ & &
\end{tabular}

Source: The farmers survey by the author, 2018.

It is a problem for farmers to borrow money/goods in farming activities to meet production costs or not to borrow. If farmers do to borrow, there will be an increase in production costs, they have to repay the loan plus interest on the loan. However, if farmers do not borrow, it is likely that the productivity of rice plants will decrease so that revenues will decrease. Borrowing options are still carried out during the farming can still generate positive income. 
The Ability of Farmers to Create Capital for Financing Rice Farming. Household income is the sum of all income received by household members, both from rice farming and non-rice farming and non-farming. The amount of household income of rice farmers is presented in Table 6.

Based on Table 6, the household incomes of own funding farmers was greater than loan funding farmers, with a difference of $44 \%$. The rice farmer income and non-farming were greater on own funding farmers than loan funding farmers, while non-rice farming income on loan funding farmers was greater than own funding farmers.

Based on Table 7 that the households' spending of own finding farmers were lower than loan funding farmers. Households' spending consists of food and non-food and other non-food items.

Table 7 - Rice Farmers household spending in South Sumatera, 2017

Source: The farmers survey by the author, 2018.

Capital creation is the difference between household income and household spending. If the difference is positive, then there is capital creation, whereas if the difference is negative it means that there is no capital creation. The data in Table 8 presents the value of capital creation of rice farmers in South Sumatra based on three types of land.

Table 8 - Capital creation of rice farming in South Sumatera, 2017

\begin{tabular}{|c|c|c|c|}
\hline \multirow{2}{*}{ Typology of Land } & \multicolumn{3}{|c|}{ Value (IDR/year) } \\
\hline & Household Income & Household Spending & Capital Creation \\
\hline Irrigation & & & \\
\hline Own Funding & $14,375,042$ & $23,133,627$ & $-8,758,585$ \\
\hline $\begin{array}{l}\text { Loan Funding } \\
\text { Swamp }\end{array}$ & $12,159,743$ & $21,482,909$ & $-9,323,166$ \\
\hline Own Funding & $43,599,143$ & $20,348,167$ & $23,250,977$ \\
\hline $\begin{array}{l}\text { Loan Funding } \\
\text { Tidal Swamp }\end{array}$ & $22,883,747$ & $22,531,733$ & 352,014 \\
\hline Own Funding & $42,143,658$ & $22,479,700$ & $19,663,958$ \\
\hline $\begin{array}{l}\text { Loan Funding } \\
\text { Average }\end{array}$ & $34,695,864$ & $22,290,733$ & $12,405,130$ \\
\hline Own Funding & $33,372,615$ & $21,987,164$ & $11,385,450$ \\
\hline $\begin{array}{l}\text { Loan Funding } \\
\text { Difference }\end{array}$ & $23,246,451$ & $22,101,792$ & $1,144,659$ \\
\hline $\begin{array}{c}\text { Value } \\
\%\end{array}$ & $\begin{array}{c}10,126,163 \\
44\end{array}$ & $\begin{array}{c}-114,628 \\
-1\end{array}$ & $\begin{array}{c}10,240,791 \\
895\end{array}$ \\
\hline
\end{tabular}

Source: The farmers survey by the author, 2018.

Based on Table 8, the capital creation in own funding farmers was nine times greater than capital creation by loan funding farmers. When viewed per typology of land, there was no capital creation in irrigated land, whereas in swamp and tidal swamp land there was a large capital creation where the creation of own funding farmers was greater than the capital creation by loan funding farmers. The difficulty of capital creation in irrigated land was because the area of paddy farming was less than one hectare $(0.52$ and 0.60 each for own funding farmers and loan funding farmers). The land area of swamp rice farming was 1.14 
and 1.17, while in tidal swamp land 1.42 and 1.82 respectively for own funding farmers and loan funding farmers. Loan funding farmers can improve capital creation by (1) reducing production costs, especially labor costs which make the biggest contribution to the costs of rice production, (2) pressing loan interest by choosing a loan source that imposes low interest 3) increasing rice productivity.

The measurement of the level of capital creation was grouped into three groups; namely low, medium and high. The basis of this level of capital creation was based on the cost of rice farming per hectare. It was classified as low if it can fulfill a portion $(50 \%)$ of farming costs, medium if it can meet $50 \%-100 \%$, and is classified as high if above $100 \%$.

Table 9 - Limits on the level of capital creation based on the typology of land, 2017

\begin{tabular}{cccc}
\hline \multirow{2}{*}{ Typology of Land } & \multicolumn{3}{c}{ Adequary limit of rice farming cost } \\
\cline { 2 - 4 } & Low $(<50 \%)$ & Medium $(50 \%-100 \%)$ & High $(>100 \%)$ \\
\hline Irrigation & & & $9,673,802$ \\
Own Funding & $4,836,901$ & $4.836 .901-9.673 .802$ & $9,058,398$ \\
Loan Funding & $4,529,199$ & $5.529 .199-9.058 .398$ & $6,902,438$ \\
$\quad$ Swamp & $3,451,219$ & $3.451 .219-6.902 .438$ & $8,324,983$ \\
Own Funding & $4,162,492$ & $4.162 .492-8.324 .983$ & $6,732,562$ \\
Loan Funding & $3,366,281$ & & $10,191,656$ \\
Tidal Swamp & $5,095,828$ & $3.366 .281-6.732 .562$ & \\
Own Funding & & $5.095 .828-10.191 .656$ & $8,041,629$ \\
Loan Funding & & & $9,218,335$ \\
Average & $4,020,815$ & $4.020 .815-8.041 .629$ & \\
Own Funding & $4,609,168$ & $4.609 .168-9.218 .335$ & \\
Loan Funding & & &
\end{tabular}

Based on the data presented in Table 9, there was not too much variation in the extent of the level of capital creation among rice land typologies and between sources of farming costs. For own funding, the highest limit for sufficiency was in irrigated land, while the lowest was in tidal swamp land. For sources of loan costs, the limit was highest on tidal swamp land, while the lowest was on swamp land.

Furthermore, based on criteria for the three levels of capital creation groups in Table 10 , it was calculated how many farmers belong to that level.

Based on the data presented in Table 10, both farmers, own funding and loan funding were mostly classified as medium capital creation level, which was $56 \%$ and $44 \%$ respectively. The lowest of capital creation is at the low level. Farmers who were categorized as high capital creation were $39 \%$ and $36 \%$ for each source of funding.

Table 10 - Level of capital creation on rice farmers in South Sumatera, 2017 


\section{CONCLUSION}

Production per hectare of own funding rice's farmers was $29 \%$ greater than farmers on loan funding farmers. This difference was contributed by tidal swamp land, which was more than doubled and $20 \%$ in swamp land, while from irrigated land it was relatively small at only $4 \%$. This larger production causes revenue to increase by more than $30 \%$, prices are relatively no different. On the other hand, producing cost of own funding farmers $26 \%$ was lower than loan funding farmers. This condition causes the income of own funding rice's farmers per hectare $56 \%$ was greater than the income of loan funding farmers.

The contribution of rice farming income to family income was dominant: $73 \%$ for own funding farmers and $75 \%$ for loan funding farmers. With the family spending were not too different, capital creation of own funding farmers was greater than loan funding farmers. Overall, almost half of the farmers have a medium level of capital creation capability $(50 \%$ $100 \%$ can cover production costs), the remaining one third was more classified as high capital creation and one-eighth was classified as low.

Efforts to reduce the dependence of rice farmers on non-formal lending institutions, the government should develop more agricultural cooperatives and simplify banking administration. To reduce rice farming cost of loan funding farmers are savings of labor costs by supervising their labor and finding sources of loans with the lowest loan interest rates.

\section{ACKNOWLEDGMENTS}

This paper is part of the Grant Competitive Universitas Sriwijaya Research in 2018, which has been funded this research complies with the letter of Agreement Assignment of Competitive Grants Research Universitas Sriwijaya in 2018.

\section{REFERENCES}

1. Antoni, M., Mulyana, E., D.M. Manalus. 2015. Analisis Komparatif Usahatani Padi Lahan Sawah Tadah Hujan Berdasarkan Perbedaan Sumber Modal di Kecamatan Lempuing Jaya Kabupaten Ogan Komering Ilir Provinsi Sumatera Selatan. Prosiding Seminar Nasional Dies Natalis ke-52 Fakultas Pertanian Universitas Sriwijaya, Palembang 5 November 2015. Antoni, M., Mulyana, E., D.M. Manalus. 2015.

2. The Central Bureau of Statistics, South Sumatera. 2017. South Sumatera in Figure 2017. The Central Bureau of Statistic, South Sumatera Province, Palembang.

3. Detik Finance. 2017. Biaya Produksi Padi di RI Lebih Mahal dari Vietnam Hingga China. https://finance.detik.com/berita-ekonomi-bisnis/d-3554841/biaya-produksi-padi-di-ri-lebihmahal-dari-vietnam-hingga-china (referd November $30^{\text {th }}, 2017$ ).

4. Jhonson, R.R. 1982. Jhonson, R.R. 1980. Elementary Statistics (Third Edition). Duxbury Press, California, USA.

5. Ministry of Agiculture Republic of Indonesia. 2017. Basis data statistik pertanian. Ministry of Agiculture Republic of Indonesia, https://aplikasi2. pertanian.go.id/bdsp2/id/lokasi (refered at November $30^{\text {th }}, 2018$ ).

6. Ministry of Agiculture Republic of Indonesia. 2017. Optimis Produksi Beras 2018, Kementan Pastikan Harga Beras Stabil http://www.pertanian.go.id/

7. Mulyaqin and Astuti, 2013. Ketersediaan dan Pemanfaatan Sumber Pembiayaan Usahatani Padi Sawah di Kabupaten Pandeglang Provinsi Banten. Buletin Ikatan 3(1): 929. 